- Draws attention to a further work of art of importance to the history of dentistry, by a major British artist.

- Demonstrating the everyday provision of dental services in the social heart of mid-eighteenth century London gives a better understanding of the historical base of modern dentistry.

- Discussing the possibility of harm from the occupational exposure of barbers to mercury reminds modern dentists of their own occupational risk.

\title{
A picture of dentistry at Charing Cross in the 1730s given by Hogarth's painting and print of Night. Professional governance, identity and possible mercury intoxication as an occupational hazard for his barber tooth-drawer
}

\author{
M. G. H. Bishop ${ }^{1}$
}

The 2006-7 exhibition of William Hogarth's (1697-1764) works in Paris, London, and Madrid' reunited his series The times of the day, first shown at his house in Leicester Fields (now Square), in 1736. Night (Fig. 1), the fourth painting in the group, is as important to the historical record of dentistry as J. M. W. Turner's painting and sketches of The dentist reproving his son's prodigality, described previously in the Journal. ${ }^{2}$

The place of Night in the canon of works relating to Barber-Surgeons has been noted in Medicine and art, by Alan and Marcia Emery. ${ }^{4}$ This paper enlarges on the dental significance of the painting and Hogarth's 1738 print (Fig. 2) of the same subject.

While Turner guides us round the interior of his dentist's rooms and laboratory, Hogarth shows us in the liveliest fashion a 'shop-window' in Charing Cross, where in the social environment of clubs and pleasure-houses and riotous street life, a barber-surgeon/tooth-drawer is working late into the night, shaving a client on a 29th May (when the Restoration of the Stuarts was celebrated with oak leaves).

'Queen Anne House, 2a St Andrew Street, Hertford, Herts, SG14 1JA

Correspondence to: Mr Malcolm Bishop

\section{Refereed Paper}

Accepted 25 April 2007

DOI: $10.1038 /$ bdj.2007.791

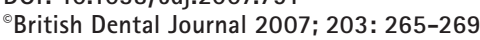

His room is brightly illuminated by candles, 12 fixed in the window frame, and a further one in a wall sconce, answering the question of how an eighteenth century operator saw to extract teeth in the dark and narrow streets of London (Charing Cross was little more than 18 feet wide) (Figs 9-10). He advertises his dual role with the traditional barber's pole, striped red and white, and a painted sign claiming 'Teeth Drawn $w^{\text {th }}$ a Touch', a fiction with benign intent (Figs 3-4). The six filled porringers on the counter-board beneath the window show the daily extent of his phlebotomy activity.

The possible identity of Hogarth's barber-surgeon/tooth-drawer

The Quarterage books of the Barber-Surgeons Company record two Yeoman Barber members at Charing Cross in 1735-6. The elder, Richard Legg (c. 1678-?), who came to London from Newport, Isle of Wight, had been apprenticed to Robert
Wood, Barber, on 5 April 1692, ${ }^{5}$ and was made free in $1699,{ }^{6}$ so in his mid-fifties he would have been older than the man shown. His erstwhile apprentice John Sanguavya [c. 1792-1747], however, would have been aged about 44 (Figs 5-6). Hogarth's reputation for 'drawing from the life' suggests one or the other as his model, with Sanguavya the right age, though he could have imported his barber, who is very distinctive, having a definitely un-English cast of feature (Fig. 11).

It is not possible to determine whether Sanguavya was a clerical corruption of his name, or whether that is what he called himself. It was as Johannes (John) Sangwin of Thettford [sic] in Norfolk that he was apprenticed by his father George to Legg on 2 May 1706, ${ }^{7}$ (Fig. 7) being made free on 2 February $1713^{8}$ (Fig. 8). His death is recorded in the Quarterage book for 1747-8.

Careful study of the Poor Rate Books [of freeholders] for Charing Cross has not 


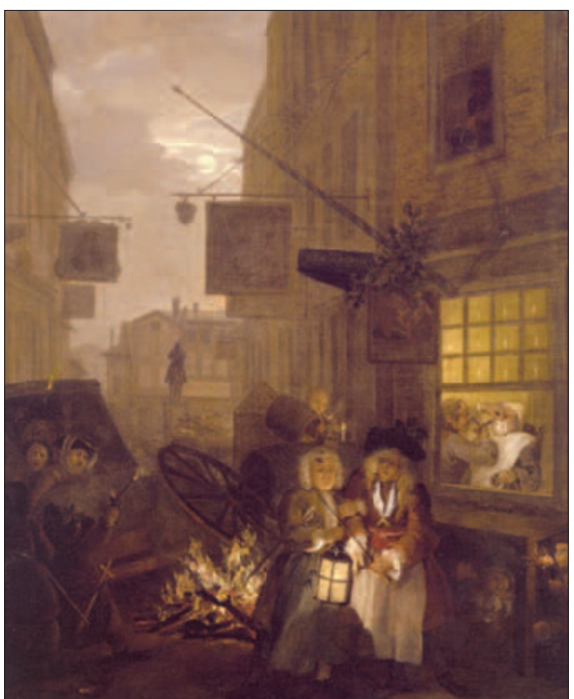

Fig. 1 Night by William Hogarth, 1736. Upton House, the Bearsted Collection (The National Trust)/NTPL/John Hammond

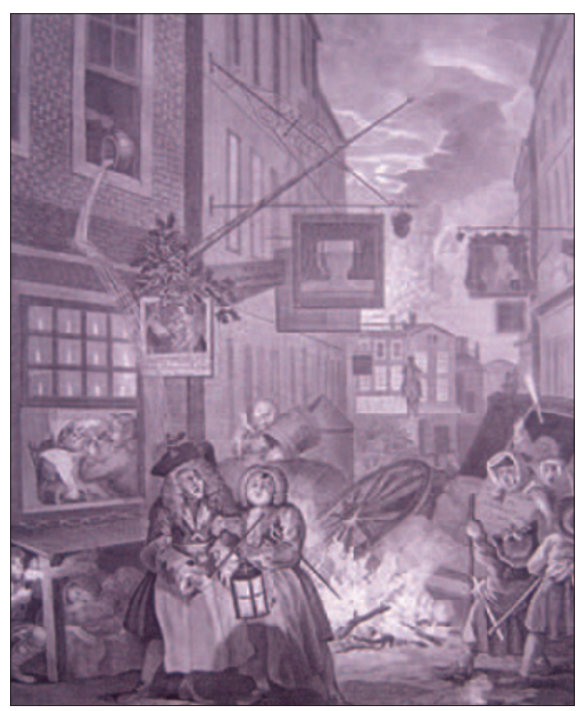

Fig. 3 Night, as engraved by William Hogarth, 1738. Private collection. Paulson No: 149

shown the names of either Legg or Sangwin, and this makes it fairly certain that they rented their accommodation, which may not have been where Hogarth shows it. The Baptism Register for St Martin's in the Fields records the birth of John Jekyl Sangwine to John and Sarah on 18 August $1724,{ }^{9}$ and the election Poll Book for $1749^{10}$ (there are no earlier Poll Books) records a John Sanguine, Victualler, on the west side of Charing Cross a year after the death of John the barber, directly opposite the Rummer rather than next door on the east side where Hogarth paints the shop ${ }^{11}$ (Fig. 10).

A John Legg (a son John was born to Richard and Mary Legg in 1709) ${ }^{12}$ appears in the 1749 Election Poll Book as 'Perfumer' at the 'Sign of the Civet Cat' opposite the

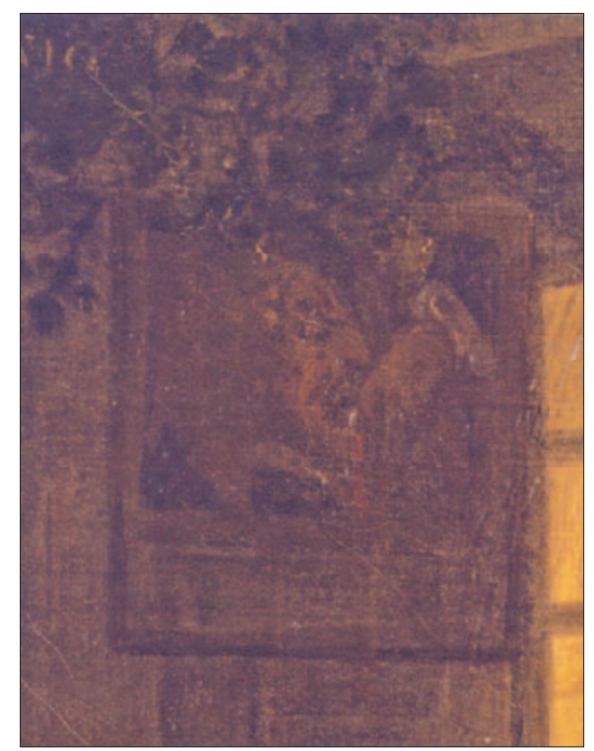

Fig. 2 The Barber's sign, barely legible, from the painting, 1736

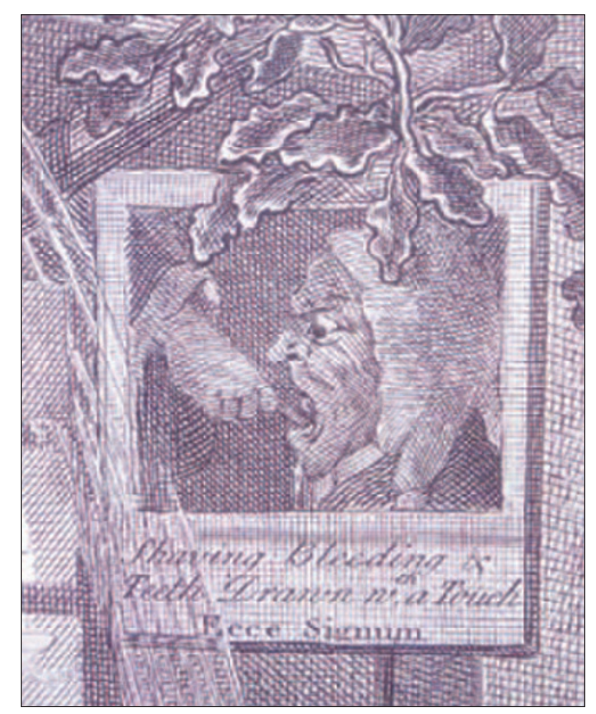

Fig. 4 The Barber's sign as revised in the engraving, 1738

Admiralty at the lower end of Charing Cross. ${ }^{13}$ In 1756 he advertised that he was selling, amongst other things, 'The genuine Delescot's Opiates and Tinctures, so famous for the Teeth, breath, gums. Likewise an excellent Pomatum to strengthen, thicken, and nourish the hair...'

The importance of Hogarth's painting in time

The 1730s showed much promise for dentistry within the Barber-Surgeon's company under the form of governance which since the Henrician Acts of $1540^{14}$ had given stability to dentistry in London (and for seven miles around) under the joint umbrella of the Company of Barber-Surgeons of London and the Church of England.
This came to an end in 1745 with the Act ${ }^{15}$ which split the Surgeons from the Barbers, but 1736, the year of Hogarth's painting, was particularly significant, since the specialist operator, John Watts (1672-1743), of Racquet Court, who had been apprenticed to the specialist Middleton, and who himself trained the famous Rutter, was elected Master of the Barber-Surgeons Company (with over 3,000 members). This made him rather more than the equivalent of the President of the General Dental Council and Chief Dental Officer combined.

As shown by a Mandate from Charles I, the election of Governors to the Barbers and Surgeons Company was no honorary posting, and the officers were answerable to the crown for the good governance of the members. ${ }^{16}$

Seventy years (perhaps four 'generations' of practitioners) separate Hogarth's Night and Turner's Dentist. Turner's painting proves that this was long enough for our professional sub-group of medicine and surgery to have acquired an acceptable name and an established independent place in society, but not as a part of the official medical world, as Hogarth's barber was. Hogarth's painting shows the last days of what we might have remained, a growing specialty within the governance of the united company.

The importance of the location of Hogarth's painting to dentistry

St Martin's Parish was one of the main foci for incoming operators for the teeth, in particular the Huguenots who brought their skills from France. Hogarth thus shows a barber-surgeon/tooth-drawer both at the very end of the long union of the barbers and surgeons, and at the turning point where specialist operators were taking the place of the barber/ tooth-drawer in metropolitan dental life.

Situated immediately behind the buildings to the West of Hogarth's Charing Cross is the Spring Garden, which features in a footnote in dental history, for it was in the chapel there on 24 April 1704, with a special licence from the Archbishop of Canterbury, that the Huguenot operator for the teeth Estienne Baron dit Dupont was married to Marie Prévereau by the Minister of the French Church of the Savoye. ${ }^{17}$

Stephen Dupont (he Anglicised his name) worked in the shadow of St Martin's in the Fields (Figs 9-10), not dying 
until 1745 , so aged 50 he is to be 'found' in the painting by turning right at the statue and immediately left into St Martin's Lane, unseen behind the buildings on the right. Others in the Huguenot community included the enterprising Pilleaus (goldsmiths, not barbers). The younger introduced the taking of wax impressions to England well before Pfaff published the technique, ${ }^{18}$ and from 1696 onwards, a barber tooth-drawer or a surgeon could obtain laboratory work from Pilleau the elder, who advertised his capability in the Post Man. ${ }^{19}$ He was not unique in this, and Gamaliel Voice, a cousin of the specialist operator Watts (Hargreaves considers it probable that they co-operated) advertised technical and denturist services on site at Lothbury, or by post, in the 1720 s and 1730s. ${ }^{20}$

\section{A pathological puzzle}

Hogarth's engraving (reversing the scene) (Fig. 2), published in 1738 at five shillings a print, was not a mere copy of the original painting, but the result of detailed editing. Amongst the several alterations is the pathological subject of this essay - as well as cutting his client, the barber is clearly shown to be drooling (Figs 11-12).

Enough information and contemporary description exists for a differential diagnosis of this phenomenon to be attempted. There are four possibilities:

1. Masonic symbolism

2. Alcohol intoxication

3. Mercury intoxication

4. A Hogarthian pun.

The first is likely, even probable. Hogarth was a Freemason, and in 1889 W. Harry Rylands described a dozen Masonic references in the print, ${ }^{20}$ although he does not mention the drooling. More recently Marie Mulvey-Roberts prepared a detailed commentary which does include the drooling. ${ }^{21}$

The second explanation, that the barber is drunk, accounting both for the drooling and for the cutting of his client, was given in 1793 by Ireland, an early biographer of Hogarth. ${ }^{22}$ This is reasonable considering that the main figure in the foreground of both painting and print is staggering drunk.

The third explanation, mercury intoxication, particularly since there are two possible occupational hazards which can be put forward as a cause, is the most relevant for consideration in this paper.

Whatever covert meaning Hogarth may have encoded in the print, it is the everyday interpretation of such drooling that would be clear to a contemporary viewer. The signs and symptoms of mercury intoxication, which include both excess salivation and loss of fine motor control, were well known to the early Georgians thanks to their use of mercury as a cure for venereal disease (syphilis and gonorrhoea had not been clearly distinguished at the time, a problem which Hunter's experiments compounded - see The knife man by Wendy Moore $^{23}$ pp 191-195). Contracting venereal disease was an occupational hazard for midwives and gynaecologists, ${ }^{24}$ and the risk for dental operators must be acknowledged.

That exposure to clients with venereal disease was likely, is shown by the extent of the problem in the parish of St Martin's as revealed by the entries for extraordinary disbursements to the hospitals from the Poor-Rate for the Parish of St Martin's in the Fields in $1734 . .^{25} 2 / 9 \mathrm{~d}$ was paid for two months' washing for one patient while in Guy's Hospital, and 5/- paid as admittance fees for another to the Salivating Ward at St Thomas's Hospital, and the Parish 'paid Mr Sabar for the cure of 26 persons of the veneral [sic] disease: $£ 9.15 /-{ }^{26}$

A different occupational possibility for the source for mercury intoxication in a barber is described by the famous eighteenth century dentist Bartholomew Ruspini in 1784. The case involved a young lady with the characteristic symptoms, dysphagia, swollen gums, 'a brassey taste' and 'a great quantity of saliva secreted from the glands'. ${ }^{27}$ Rather than jump to the obvious conclusion, to the damage of the reputation of the patient, Ruspini made close enquiry of the lady's maids and then her hairdresser, and found that the latter had supplied a preparation to deal with lice ('Animalculae breeding in the hair'), which contained mercury. Any barber who prepared or administered the ointment by rubbing it in would himself have been at risk of intoxication. As Ruspini said '...some constitutions are affected by the smallest quantities of Mercury, even externally applied.'

Weight is given to this occupational source since the barber is shown still working by Hogarth, while the 'salivation cure' tended to be an in-patient activity. In his fictionalised autobiographical contemporary novel Roderick Random the Scottish medical author Smollett shows his 'hero' shutting himself away for a 'cure'. ${ }^{28}$ (Also see plate 5 of The harlot's progress [Hogarth 1732] where 'Moll' is submitting to a 'cure'.)

There is no mention in the Rate Book of either Legg or Sangwin needing parish support for a 'salivating cure' nor is there any break in their payments of quarterage to the barber-surgeons, and both seem to have had healthy children.

The fourth explanation, which refers only to the Barber cutting his client and the dark appearance of the barber himself, is that of a Hogarthian pun confirming the identification of the barber

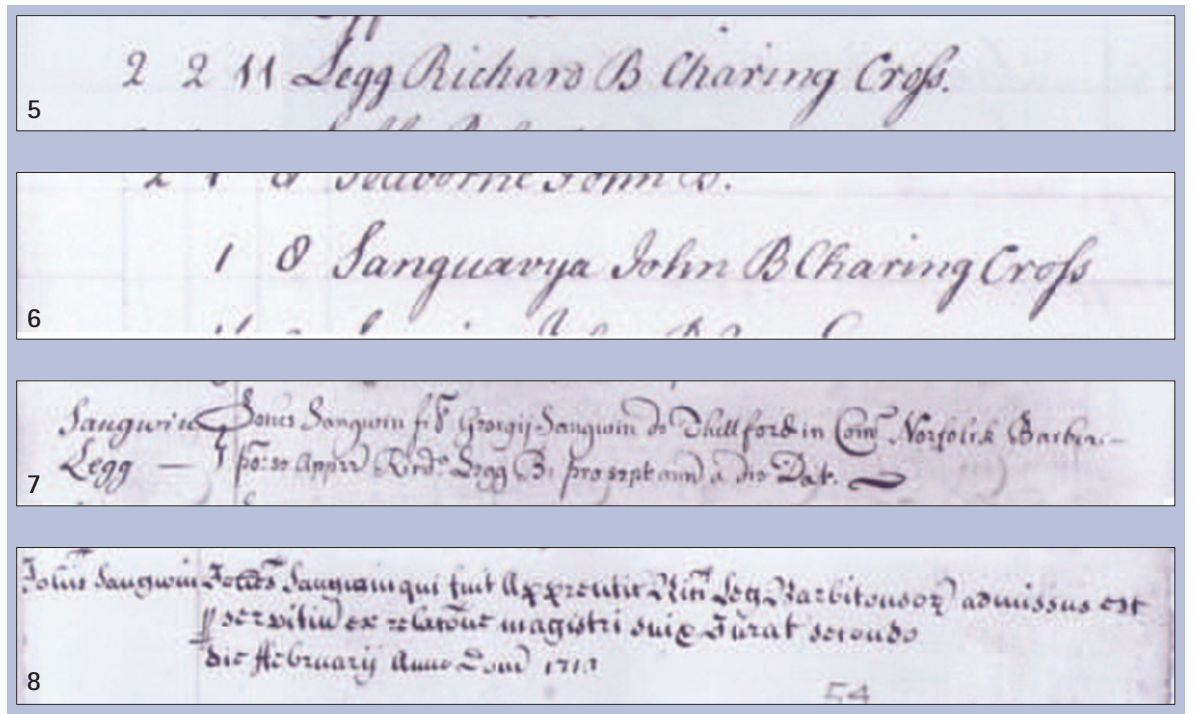

Figs 5-8 Copyright Guildhall Library. By kind permission, the Honourable Company of Barber Surgeons of London. Photography: Geremy Butler 
as John Sangwin - both ruddy complexioned (the surname's derivation) and 'bloody' (a pun to be found recently in the naming of a vampire in a Harry Potter adventure ${ }^{29}$ ).

Epitaph: the personal story hidden in Hogarth's lighting

In 1735 there was a fire in Cecil Court (in the background position shown in both painting and print), where Hogarth's widowed mother Anne lived close to his own house in Leicester Fields (Fig. 9). Two entries in the Gentleman's Magazine tell the story, the first recounting the circumstances:

'A fire broke out at Mrs Calloway's a brandy-shop in Cecil Court in St Martin's lane, which in a few hours consumed that and 13 more houses. The woman was committed to Newgate, it appearing, among other circumstances, that she had threaten'd to be even with the landlord for having given her warning, and that she would have a bonfire on the $10^{\text {th }}$ of June that should warm all her rascally neighbours.'

The second records the tragic consequence in the notices of deaths:

'MRS HOGARTH, mother of the celebrated Mr. Hogarth, of a Fright occasioned by the Fire. ${ }^{30}$

Where we are given farce in the foreground, there is tragedy in the background.

\section{SUMMARY}

The barber-surgeon tooth-drawer of 300 years ago in London was a practitioner whose professional governance and working life was comparable with that of the general dental practitioner of today. He or she had to be registered with the Barber-Surgeons Company after a seven year apprenticeship, he or she was accountable to the Company for good behaviour, and had to pay Quarterage - a form of annual retention fee.

He or she (female barbers are listed separately in the Quarterage books) practised at a known and publicly identified address, and the records show long periods (at least 40 years for Legg ${ }^{31}$ and Sangwin) of continued professional activity. Their work as barbers kept them in regular contact with potential patients, who could trust them when unpleasant dental treatment was required.

Legitimate practice included extraction, scaling, provision of toothpowders,

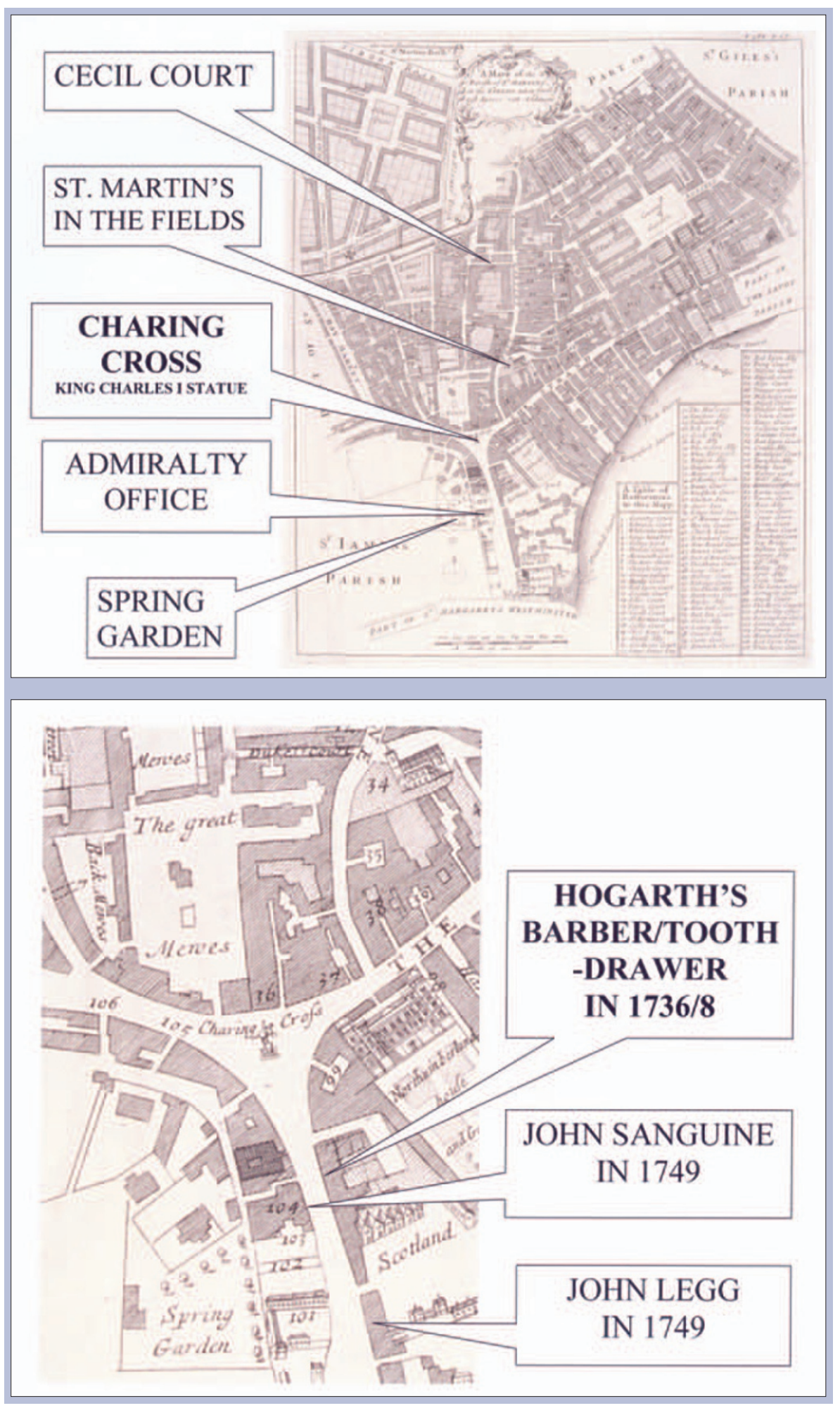

Figs 9-10 Map of the Parish of St Martin's in the Fields, and detail, Stowe's Survey of London, 1720 showing sites mentioned in the text. By kind permission, Guildhall Library; Corporation of London

prescription of oral medicines, and if prosthetic work was rare, it should be remembered that in expense and technical difficulty such provision was comparable with implants today. For the academic theory of practice, the would-be specialist - though perhaps not the Charing Cross tooth-drawer - had, in Charles Allen's 1686 book
The operator for the teeth ${ }^{32}$ a text-book well pre-dating Fauchard's (admittedly much more comprehensive) text of $1746,{ }^{33}$ which was not available in English.

In 1877 the British Museum catalogue referred to Riepenhausen's (1775) re-engraving of part of the scene as showing 'the sign-board of the dentist' 

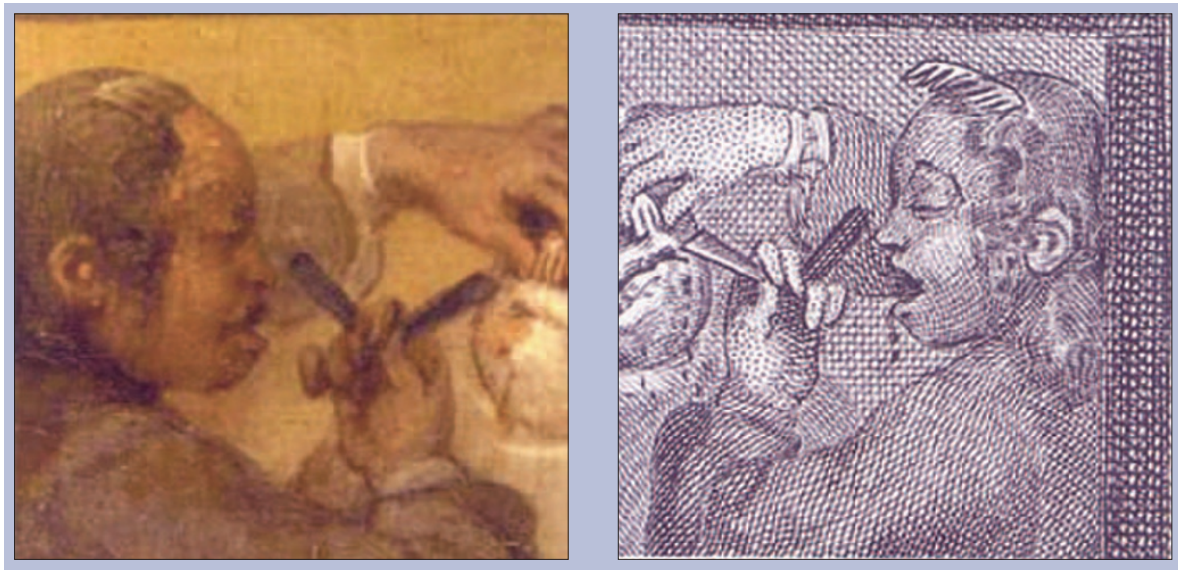

Figs 11-12 The painting and the print of the Barber, showing his un-English appearance, and his drooling in the print

revealing acceptance of the barbersurgeon as ancestor to today's general practitioner.

That these men and women earned a living by mixing shaving, barbery, and bleeding with their dental activities does not seem as strange now as it might have seemed just a few years ago when dentists did not advertise their willingness to provide cosmetic services outside the dental field.

Much of value to dental historians has been learnt from those in the past who advertised their services, but those who advertise are not, then or now, necessarily representative of a profession. Like Turner's Dentist painting and its suggested real life characters who show dental life in 1808, Hogarth's Night provides a rich vehicle for studying humdrum everyday dental services in the 1730s.

The assistance of the librarians of the Athenaeum, the British Dental Association, the Guildhall Library, the Library and Museum of Freemasonry, and Westminster City Archive, is gratefully acknowledged.
1. Hallett M, Riding C. Hogarth Catalogue Raisonnée for the exhibitions held at the Musée du Louvre, Tate Britain, La Caixa. London: Tate Publishing, 2006.

2. Bishop M G H, Gelbier S, King J. J. M. W. Turner's painting The unpaid bill, or the dentist reproving his son's prodigality. Br Dent J 2004; 197: 757-762.

3. Bishop M G H, Gelbier S, King J. Science and technology in Turner's Georgian dentist's rooms. Br Dent J 2004; 198: 299-305.

4. Emery A E H, Emery M L H. Medicine and art. London: RSM Press, 2002.

5. Barber-Surgeons Company Apprentice Bindings 1672-1707. Vol 2. p 474. Library of London Guildhall microfilm 5266/2. p 298.

6. Barber-Surgeons Company Freedom Register. Vol 3. p 48 [according to the index - not found there]. Library of London Guildhall microfilm 5265/3.

7. Barber-Surgeons Company Apprentice Bindings 1672-1707. Vol 2. p 474. Library of London Guildhall microfilm 5266/2.

8. Barber-Surgeons Company Freedom Register 1707-1732. Vol 4. p 54. Library of London Guildhal microfilm 5265/4.

9. St Martin's in the Fields Baptism Register. Vol 10; 1723-1732. p 22. Westminster City Archive: St Martin's in the Fields Parish Registers. Microfilm Vol 12. p 22.

10. Election Poll Book for 1749. Westminster Public Library.

11. Phillips H. Mid-Georgian London. A topographical and social survey of Central London about 1750. p 96. London: Collins, 1964.

12. St Martin's in the Fields Baptism Register. July 1706-October 1717. Westminster City Archive; St Martin's in the Fields Parish Registers. Microfilm
Vol 10. pp un-numbered.

13. General Advertiser. 1756

14. 32 Henry VIII c.42. 1540 An Act concerning Barbours and Surgeons to be of one companie. 34 \&t35 Henry VIII c.8 A Bill that Persons, being no common Surgeons, may minister Medicines, notwithstanding the Statute.

15. $18 \mathrm{Geo}$ II c15. An Act for making the Surgeons of London and the Barbers of London two separate and distinct Corporations.

16. Charles I. The Mandate of $23^{\text {rd }}$ March 1639 Elections of Governors to the Barbers and Surgeons Company.

17. Hargreaves A S. White as Whales Bone Dental Services in Early Modern England. pp 88-89. Leeds: Northern Universities Press, 1998.

18. Noted by Hargreaves op.cit. p 93 (on the evidence of a letter quoted by Lilian Lindsay).

19. Hargreaves A S. 1998, op.cit. p 92.

20. Hargreaves A S. 1998, op.cit. p 166-167.

21. Mulvey-Roberts M. Hogarth on the Square: the Masonic Metaphors of Secrecy, Perjury and Punishment. Library and Museum of Freemasonry. Unpublished ms. BE 68 (HOG) MUL/01.

22. Ireland J. Hogarth illustrated. $2^{\text {nd }}$ ed. p 148. London: J \&t J Boydell, 1793.

23. Rowling J K. Harry Potter and the half-blood prince. p 295. London: Bloomsbury, 2005.

24. Moore W. The knife man. The extraordinary life and times of John Hunter, father of modern surgery. London: Bantam Press, 2005.

25. Loudon I. Semmelweis and his thesis. JR Soc Med 2005; 98: 555.

26. The Rate Books for the Parish of St Martin's in the Fields. Westminster Library and Archives www. westminster.gov.uk/archives. Film 1577.1734 pp 311-312.

27. Extraordinary disbursements. The Rate Books for the Parish of St Martin's in the Fields. Westminster Library and Archives. Film 1577. 1734 p 312.

28. Ruspini B. A treatise on the teeth. New ed. pp 86-89. London: published by the author, 1784.

29. Smollett T. Roderick random. World's Classics ed. $1^{\text {st }}$ ed 1748. Chapter 21. London: Oxford University Press, 1930.

30. Gentleman's Magazine. The Monthly Intelligencer: Domestick Occurrences Volume 5. pp 330, 333. June 1735.

31. The earliest full Quarterage book shows Legg at Charing Cross in 1717. 9815/1. p un-numbered, alphabetical entry.

32. Allen C. The operator for the teeth. York: 1685 ; Dublin: 1686.

33. Fauchard P. Le chirurgien dentiste, ou traité des dents. Paris: Mariette, 1746.

34. Stephens F G (ed). Catalogue of Political and Personal Satires preserved in the Department of Prints and Drawings in the British Museum Vol III Part 1 p 275. 1734-1750. 